\title{
Impact of Project-Based Learning on Networking and Communications Competences
}

\author{
Cristian Castro-Vargas ${ }^{1}$, Maritza Cabana-Caceres ${ }^{2}$, Laberiano Andrade-Arenas ${ }^{3}$ \\ Faculty of Sciences and Engineering \\ Univerisdad de Cienciasy Humanidades \\ Lima Perú
}

\begin{abstract}
The objective of this article is to establish the impact of project-based learning on networking and communication competences $I$ in engineering students from Lima city. The study was of an applied type, quasi-experimental design, and was made up of a population conformed by 39 students of the VI cycle of engineering, an objective test was applied to measure the impact of project-based learning on network and communication competences I. The research results determined the statistically significant relationship of projectbased learning and networking and communications competences $I$ in engineering studentswith pretest values of $Z=$-, 498 greater than -1.96 (critical point) and level of significance $p$ value $=0.618$ greater than $\alpha=0,05(p>\alpha)$ and then with values in the posttest of $Z=-4,488$ less than -1.96 (critical point) and level of significance $p$-value $=0.000$ less than $\alpha=0.05(p<\alpha)$, therefore the project-based learning positively and significantly impacts on network and communication competences $I$, in engineering students, supporting the alternative hypothesis and rejecting the null hypothesis. Consequently, we reached the conclusion that the application of the project-based learning methodology has demonstrated that caused a positive and significant impact on network and communications competences $I$ in engineering students.
\end{abstract}

Keywords-Project-based learning; competencies; networking; communications; network convergence

\section{INTRODUCTION}

The rapid changes that occur in the job sector as a result of globalization do not find future engineering students with the skills in networks and communications for an adequate professional development. Higher educational programs do not correctly manage the development of professional competences holistic or comprehensive [1]. The Organization for Economic Co-operation and Development (OECD) indicated that professionals have difficulties in performing properly in the company because they are not aware of the importance of development in network skills and communications, generating not enough contributions in society which worldwide in the coming years will need millions of dozens of jobs that will require that they have competences in the specialty to solve problems in this field [2]. Furthermore, each network technology manufacturer develops new implementations of Network and Communications Convergence, generating the need for more trained professionals in these new technological competences. According to the United Nations Educational, Scientific and Cultural Organization UNESCO [3] mentioned that all this leads to pressure on academic institutions of higher education, whether in the public or private sector.

In Latin America [4] they were classified as one of the problems, is that not all students have the availability to adapt to work academic-training activities in a collaborative way, although the student team tries to include them, they have rigid behavior when presenting tasks individually, they do not accept changes to new situations and also they cannot communicate their ideas.

In the case of Perú, the concern of the Organization for Economic Co-operation and Development (OECD) [5] found that the student in his university training does not have the competences in the adequate communications network to be able to cover jobs competitively. This is worrisome when considering that overall the penetration of some Information and Communications Technologies (e.g., the Internet) have been gradually increasing in this Latin American nation [6]. Due to this he does not adapt quickly to technological changes, its development is insufficient, and it is vulnerable to inserting itself in the labor population, which is why the National Superintendence of Higher Education SUNEDU [7] mentioned that it is still due to the disorder that exists between the labor markets and higher education, it generates a complex academic problem due to the inequality between the information that is handled in the university that does not contrast with the problems that the market asks to solve, reflecting this in his professional life through inconsequential work jobs. In the university, instead of the research, the teaching of specific and formative knowledge prevails, but it is not enough to achieve an integral formation of the students who agree to achieve competitiveness, whether national or international. Therefore, the research problem is focused on strengthening the student competencies, which in some cases it has not been prioritized in the course of networks and communications.

In Brazil, a study evaluated 20 students for every 4 semesters, with a maximum reference of 10 , all the students obtained a score of 8 at the end. As a conclusion of the research, it was found that when carrying out the implementation of the network infrastructure, the experimental group evolved better because they oriented the activities to projects with real problems, they also found a greater commitment to meet the challenges, leading them to search and analyze the best possible solution and understanding of the functionality of the correct design that a data network should have, thus also leading them to have a greater social awareness for the participation in carrying out the projects [8]. 
In the USA, Rice University, Houston, Texas, researchers carried out a quasi-experimental study, of a student sample equal to 5492 of science and engineering, the participants rated the extent to which they were going to be effective in executing STEM tasks on a Likert-type scale of 6 items, descriptive statistics, correlation $\mathrm{r}=5.194, \mathrm{p}<0.001$ for STEM efficacy competences. It was concluded that the university investment in active learning activities such as $\mathrm{PjBL}$ will pay off by increasing student participation and interest in the STEM career [9].

In Spain, a study considered a sample of 50 students and 1 teacher. Its objective was to teach students the importance of the network course, to enhance learning and the acquisition of basic competences of the subject, through project-based learning to achieve better performance of the competences of the subject of networks, to establish the level of participation an evaluation of self-correction mechanisms of the projects was applied to the students. It was concluded that the realization of projects is positive for the learning of communication networks, because it allows them a better acquisition of competences, as well as gaining previous experience for professional performance, verifying with the growth of $70 \%$ of good level of the students in the course at the end of the course [10].

In China, a research work was conducted with a population of 80 students. It was concluded that project-based learning not only cultivates student initiative, but also improves their collaborative, practical, and project planning capabilities, as well as the student recognizes how extracurricular time can be used well with this system [11].

The National University of San Agustín de Arequipa, considered a population of 74 students distributed in 4 groups, carried out 9 sessions, aimed to apply the project-based learning methodology to the engineering course to verify better achievement in their professional training competencies. The project-based learning methodology was concluded, which strengthens and increases knowledge, as well as improves the competences, abilities and attitudes of understanding the course, with $72 \%$ between the level of good and excellent as a final result [12].

The Universidad Peruana Cayetano Heredia, carried out a study of a quantitative approach and quasi-experimental design, of a population of 76 students, aimed to check the effect of using the virtual platform to improve competences and learn the network course and communications, obtaining as results a significant improvement verifying in the notes at the beginning of $9.24(65 \%)$ in the pretest and at the end of 15.6 $(90 \%)$ in the posttest of the students, having as a conclusion that employment of the active methodology improves the level of competences in the course of networks and communications [13].

Likewise, at the César Vallejo University, it considered a population equal to 158 students, a non-probabilistic, intentional sample, 57 from the group belong to the experimental group and 60 belong to the control group. I do 8 sessions with the project-based learning methodology for the experimental group. Using a questionnaire instrument of 34 consultations divided into seven dimensions where the level of investigative competences was evaluated, showing improvements due to the use of project-based learning. The non-parametric Mann-Whitney U test was applied, determining the statistical significance $\mathrm{p}=0.00$. Concluding that the application of project-based learning allowed a significant improvement in the level of investigative competences of the experimental group [14].

The San Luis Gonzaga National University of Ica, with a population of 80 students, considered two groups of 40 equal for the experimental and the control, whose objective was to establish the influence of project-based learning on the competencies in systems engineering students. In conclusion, collaborative project-based learning improved the acquisition of competences in Engineering students, as well as a greater ability to: conception, design, development, effective use of engineering techniques and tools, reflected in the notes. The pretest the mean was 13.98 and in the end in the posttest improvements were obtained with a mean 17 , achieving a $p$ value equal to 0.00 [15].

At the National University of Engineering, a census sample of 36 students of the VI cycle of engineering was considered, divided into two groups: 17 control and 19 experimental, and performed the non-parametric U test of Mann Whitney, whose objective was to determine the effect of the application of a sustained program in project-based learning methodology in the development of competencies in students. Concluding the experimental group, he developed the procedural and attitudinal cognitive competences of the course, applying the knowledge acquired in the execution of a project similar to an activity in the professional field, achieving a p-value $=0.000$ [16].

For the variable impact of project-based learning, constructivism was considered as a theoretical approach [17] because it refers to the use of learning resources associated with appropriate scientific methods or learning models, for which this model allows the allocation of time For the design of learning resources, the project-based learning methodology thus generally allows for better development in the institution's learning-teaching processes. Constructivism [18] according to Piaget's theory, indicated that there is a close similarity between project-based learning and constructivism, because there is an active process, permanent participation among students going through various experiences to try to contrast solutions to the problem that normally occurs in a real environment. Project-based learning is a pedagogical approach due to the following characteristics: Students are active during learning through cooperative participation in scientific and engineering practices, students create a set of tangible products and shared artifacts that are accessible to the public to external representations [19].

In this regard, project-based learning is developed by the theory of active learning which is constructivism, and is a learning model that allows to increase learning in students; the habit and the creation of new learning practices, because students have to originally think for the real-life problem, the solution, centered on the student as it allows constant discovery [20]. In the same sense, it encourages the development of transversal competences and promotes autonomy [21]. To 
obtain a good learning requires learning environments of higher education conducive to a better development of metacognitive competences [22].

Regarding the theoretical approach of Network and Communications Competences I, it is considered belonging to constructivism. According to Piaget, he maintains that the student builds his own knowledge through the experience of carrying out the assigned activities, obtaining practical results, using the approach of constructionism, which maintains that it is an action-based learning, which allows the student to have a mental structure related to the concrete action, which will allow him to generate a motivation for learning, thus obtaining a correct intellectual construction given by the exchange and the assigned work that is being developed, also generating intellectual and affective autonomy. Another theoretical consideration is the connectivism approach, according to George Siemens [23].

Regarding the definition of the dependent variable network and communications competences I, according to the curriculum EAP Professional Academic School of Systems Engineering, defined it as the curricular experience of networks and communications I belonging to the professional training area and it is theoretical - practical compulsory, with the purpose of creating in the student the competences in design, implementation and administration of computer networks, using both information and communication technologies for the development of the following aspects: Networking, switching, routing and wan technologies [24]. Hence, competence was defined as "an ability to act effectively in a defined type of situation, an ability that relies on knowledge but is not reduced to it" [25].

The computer network was defined as "a communication system that connects two or more computers to each other by means of such optical fibers, radio waves, and electromagnetic waves, allowing them to share information and services." [26]. Regarding the definition of a communication network, it is necessary to interconnect different computer systems throughout the wan, using internet [27]. Academic competencies are the essential knowledge that is learned during general training and are classified into: writing, problem solving, mathematics, reading ability, creative thinking, assertive communication, decision making, assimilation and comprehension, learning and reasoning [28].

The curriculum of the Academic Professional School EAP Systems Engineering dimensioned the competences of networks and communications I: knowledge to solve problems of local area network design, implementation of network convergence and network administration [24]. Theoretically, project-based learning and network and communications competencies are justified. Both have an affinity because they allow the use of characteristics between them such as analysis, planning and design, guiding them to the correct development of similar problem solutions to the professional field.

Thus, there is also an epistemological justification between project-based learning and the competences of the course on networks and communications $\mathrm{I}$, which is given such justification because they refer to the theory of constructivism, which affects having the student as a direct participant in their learning within the problems that they must understand in order to build or guide concepts to solve said problem [24].

The purpose of this research is to determine the impact of project-based learning on the competences of networks and communications I, in engineering students, which is dictated the sixth cycle of the specialty of Engineering, of Systems of the University of Sciences and Humanities.

In Section II we present the methodology followed to obtain the results shown in this study, in Section III presents our results, in Section IV we present the discussion, in Section V we present the conclusions and finally in Section VI we present the recommendations.

\section{Methodological FramewORK}

The present study is based on the positivist paradigm. Thus, the present investigation predicts and controls the phenomena thus verifies theories, being the external observer investigator of the events, which is based on the positivist paradigm [29].

The approach is quantitative because it is the concrete expression of reality, for which it considers as a means of reaching knowledge, explanation, prediction, control of the phenomenon, verification of theories [29]. Because they use criteria such as: validity, objectivity, reliability, statistics, experimentation, used in questionnaires, tests and then data analysis using inferential and descriptive statistics.

The level of investigation is explanatory. The objective is to verify the causal hypotheses, following a sequence of processes or organized steps [30].

The type of research is applied because it is based on the theoretical framework and is practical. The research design is quasi-experimental, quasi-experimental designs come to be strategies for conducting research in order to evaluate the impact of the set of methods carried out, for this purpose it considers two groups, one control and the other experimental through a pretest and at the end of the process the posttest evaluation, in order to demonstrate the hypothesis raised at the beginning [31].

\section{A. Variable Operationalization}

Regarding the conceptual definition of the dependent variable: Network and communications competences I, according to the EAP Professional Academic School of Systems Engineering, networks and communications curricular experience I belongs to the professional training area and is theoretical-practical compulsory, with the purpose of creating in the student the competences in design, implementation and administration of computer networks, using both information and communication technologies for the development of the following aspects: Networking, switching, routing and wan technologies (Internetworking) [24].

To operationalize the impact variable of project-based learning, an organizational matrix was developed, distributed in 10 sessions of 3 academic units (Table I).

For the operationalization of the dependent variable network and communications competences I, a 20-question questionnaire was prepared, on a dichotomous scale containing the indicators of the three dimensions: knowledge to solve 
local area network design problems, implementation of the convergence of the network and network administration (Table II).

\section{B. Population}

The population comes to be a finite set of people or objects that have common characteristics, susceptible to a study and later allow to replicate the findings in other populations [30].

TABLE I. ORGANIZATION MATRIX OF THE INDEPENDENT VARIABLE LEARNING BASED ON PROJECTS

\begin{tabular}{|c|c|c|c|}
\hline Units & $\begin{array}{l}\text { Strategic } \\
\text { activities }\end{array}$ & Phases & Indicators \\
\hline $\begin{array}{c}\text { Local area } \\
\text { network } \\
\text { design }\end{array}$ & \multirow{4}{*}{$\begin{array}{l}\text { Session 1: } \\
\text { Local area } \\
\quad \text { networks } \\
\text { Session 2: } \\
\text { Structured wiring } \\
\text { Session 3: } \\
\text { Local area } \\
\quad \text { networks } \\
\text { wireless } \\
\text { Session 4: } \\
\text { Wireless Security } \\
\\
\text { Session 5: } \\
\text { IP Telephony. }\end{array}$} & $\begin{array}{l}\text { 1. Key } \\
\text { question } \\
\text { definition }\end{array}$ & $\begin{array}{l}\text { - Event or } \\
\text { occurrence. } \\
\text { Spontaneous } \\
\text { interest in the } \\
\text { student } \\
\text { - Community } \\
\text { proposal } \\
\text { - Values } \\
\text { educational } \\
\text { power } \\
\text { - Causes a } \\
\text { commitment } \\
\text { - Responds to your } \\
\text { interests } \\
\text { - Social relevance } \\
\text { - Listening and } \\
\text { creative attitude } \\
\text { - Project } \\
\text { appointment }\end{array}$ \\
\hline \multirow{3}{*}{$\begin{array}{l}\text { Network } \\
\text { convergence } \\
\text { Network } \\
\text { administratio } \\
\text { n }\end{array}$} & & $\begin{array}{l}\text { 2. Work } \\
\text { plan- } \\
\text { calendar }\end{array}$ & $\begin{array}{l}\text { - Interaction } \\
\text { Motivation } \\
\text { - Collective } \\
\text { thinking } \\
\text { Research lines } \\
\text { - Different } \\
\text { strategies - } \\
\text { Different } \\
\text { itineraries } \\
\text { - Decide what to do } \\
\text { - Feel capable } \\
\text { - Timeline }\end{array}$ \\
\hline & & $\begin{array}{l}\text { 3. Follow-up } \\
\text { monitoring }\end{array}$ & $\begin{array}{l}\text { - Learning moves } \\
\text { to action } \\
\text { - Multiple } \\
\text { intelligences • } \\
\text { Cooperation } \\
\text { - SWOT tool • } \\
\text { Creative tools } \\
\text { - Collect materials } \\
\text { - Individual and } \\
\text { group self- } \\
\text { assessment tools }\end{array}$ \\
\hline & & $\begin{array}{l}4 . \\
\text { Evaluation }\end{array}$ & $\begin{array}{l}\text { - I've learned } \\
\text { - What is it for } \\
\text { - What do I do with } \\
\text { it? } \\
\text { - Tools (portfolio, } \\
\text { learning journal, } \\
\text { rubric, } \\
\text { assessment } \\
\text { notes) }\end{array}$ \\
\hline
\end{tabular}

TABLE II. OPERATIONALIZATION MATRIX OF THE DEPENDENT VARIABLE COMPETENCES OF NETWORKS AND COMMUNICATIONS I

\begin{tabular}{|c|c|c|c|c|c|}
\hline Dimensions & Indicators & $\begin{array}{l}\text { Ite } \\
\text { m }\end{array}$ & Value scale & $\begin{array}{l}\text { Dimensio } \\
\mathrm{n} \text { levels }\end{array}$ & Levels \\
\hline \multirow{4}{*}{$\begin{array}{l}\text { 1. Knowledge } \\
\text { to solve local } \\
\text { area network } \\
\text { design } \\
\text { problems }\end{array}$} & $\begin{array}{l}1.1 . \\
\text { Configure } \\
\text { PCs to } \\
\text { share } \\
\text { resources }\end{array}$ & $\begin{array}{l}1 \\
2\end{array}$ & & \multirow{4}{*}{$\begin{array}{l}\text { Bad: } \\
\text { [00 - 03] } \\
\text { Regular: } \\
\text { [04 - 06] } \\
\text { Good: } \\
\text { [07 - 08] }\end{array}$} & \\
\hline & $\begin{array}{l}1.2 . \\
\text { Connectori } \\
\text { ze the work } \\
\text { area wiring }\end{array}$ & $\begin{array}{l}3 \\
4\end{array}$ & & & Bad: \\
\hline & $\begin{array}{l}1.3 . \\
\text { Implement } \\
\text { a small } \\
\text { wireless } \\
\text { network }\end{array}$ & 6 & $\begin{array}{l}\text { Dichoto } \\
\text { mous }\end{array}$ & & $\begin{array}{l}{[00} \\
- \\
10]\end{array}$ \\
\hline & $\begin{array}{l}1.4 . \\
\text { Configure } \\
\text { the security } \\
\text { of a } \\
\text { wireless } \\
\text { local area } \\
\text { network }\end{array}$ & 7 & & & \\
\hline \multirow{3}{*}{$\begin{array}{l}2 . \\
\text { Implementati } \\
\text { on of the } \\
\text { network } \\
\text { convergence }\end{array}$} & $\begin{array}{l}2.1 . \\
\text { Configure } \\
\text { IP phones } \\
\text { and } \\
\text { softphones }\end{array}$ & 9 & & \multirow{3}{*}{$\begin{array}{l}\text { Bad: } \\
\text { [00 - 01] } \\
\text { Regular: } \\
\text { [02] } \\
\text { Good: } \\
\text { [03] }\end{array}$} & $\begin{array}{l}\text { Regula } \\
\text { r: }\end{array}$ \\
\hline & $\begin{array}{l}2.2 \text {. } \\
\text { Configure } \\
\text { the services } \\
\text { of an IP } \\
\text { telephone } \\
\text { exchange }\end{array}$ & $0^{1}$ & $\begin{array}{c}0: \\
\text { Incorrect }\end{array}$ & & $\begin{array}{l}{[11} \\
- \\
15]\end{array}$ \\
\hline & $\begin{array}{l}2.3 . \text { Install } \\
\text { the } \\
\text { softPBX }\end{array}$ & $1^{1}$ & & & \\
\hline \multirow{4}{*}{$\begin{array}{l}\text { 3. Network } \\
\text { administration }\end{array}$} & $\begin{array}{l}\text { 3.1. Basicly } \\
\text { configure } \\
\text { the Cisco } \\
\text { switch }\end{array}$ & $2_{3}^{1}$ & & \multirow{4}{*}{$\begin{array}{l}\text { Bad: } \\
\text { [00 - 03] } \\
\text { Regular: } \\
\text { [04 - 06] } \\
\text { Good: } \\
\text { [07 - 09] }\end{array}$} & Good: \\
\hline & $\begin{array}{l}3.2 . \\
\text { Basically } \\
\text { configure } \\
\text { the Cisco } \\
\text { Router }\end{array}$ & $4_{5}^{1}$ & 1: correct & & $\begin{array}{l}{[16} \\
- \\
20]\end{array}$ \\
\hline & $\begin{array}{l}\text { 3.3. Install } \\
\text { and operate } \\
\text { end device } \\
\text { monitoring } \\
\text { tool }\end{array}$ & $\begin{array}{l}6 \\
6 \\
7\end{array}$ & & & \\
\hline & $\begin{array}{l}\text { 3.4. } \\
\text { Monitor the } \\
\text { events of } \\
\text { the } \\
\text { Switches } \\
\text { and Router. }\end{array}$ & $\begin{array}{l}1 \\
819 \\
20\end{array}$ & & & \\
\hline
\end{tabular}

The population considered comes to be 39 Engineering students, from the Private University of the engineering career, who develop the academic cycles of the VI cycle of the network and communications course I (Table III). 
TABLE III. POPULATION

\begin{tabular}{|l|l|l|l|l|}
\hline No. & Sections & Males & Ladies & Totals \\
\hline 1 & Sixth Cycle A1Experimental Group & 14 & 5 & 19 \\
\hline 2 & Sixth Cycle C1 Control Group & 15 & 5 & 20 \\
\hline & TOTAL & 39 \\
\hline
\end{tabular}

\section{Techniques, Data Collection Instruments, Validity and} Reliability

The technique used was the survey, which allowed data to be obtained on the variable under study network and communications competences I. Thus, the instrument used was to collect data on a knowledge test of network and communications competences I.

The factor analysis to measure network and communications competences I through its 20 items, is used to test whether the items that make up each factor can generate correspondence between the dimensions proposed, obtaining that the KMO value is equal to. 610 , which indicates that there is a relationship between the values reached and the chosen sample (Table IV).

To establish reliability, a pilot test was carried out to verify the reliability of the research instrument, to a population of 30 students, which had to eliminate some items, to improve the reliability of the instruments. Once the correction was made, the instruments were applied again to the study population, obtaining a KR-20 value equal to 0.860 for the variable network and communications competences I, verifying high reliability (Table V).

TABLE IV. ADAPTATION ANALYSIS TO THE FACTORY ANALYSIS

\begin{tabular}{|l|l|l|}
\hline \multicolumn{2}{|l|}{ Statistical } & Value \\
\hline \multicolumn{2}{|c|}{ Kaiser-Meyer-Olkin measure of sampling adequacy } & 0.61 \\
\hline \multirow{3}{*}{ Bartlett's sphericity test } & Approx. Chi squared & 345,434 \\
\cline { 2 - 3 } & $\mathrm{gl}$ & 190 \\
\cline { 2 - 3 } & Sig. & 0 \\
\hline
\end{tabular}

TABLE V. INSTRUMENT RELIABILITY

\begin{tabular}{|l|l|l|l|}
\hline Variables & $\begin{array}{l}\text { Reliability } \\
\text { Statistics }\end{array}$ & Value & $\begin{array}{l}\text { No. of } \\
\text { elements }\end{array}$ \\
\hline $\begin{array}{l}\text { Networking and communications } \\
\text { competences I }\end{array}$ & $\begin{array}{l}\text { Kuder- } \\
\text { Richardson }\end{array}$ & 0.860 & 30 \\
\hline
\end{tabular}

\section{Process}

It was carried out through the construction of a questionnaire, to evaluate the use of the project-based learning methodology in the skills of the network and communications course I, consisting of 20 questions which was validated by 5 experts. To do this, he coordinated with the management of the systems engineering school through which he sent a request to the director to authorize the examination of 20 questions. After the authorization of the application was validated, the date for the examination evaluation was coordinated with the students. The next stage was the development of the project-based learning methodology for 10 sessions, culminating the same, we proceeded at the end of the cycle with the examination agreed upon both for the experimental group and for the control group. The guidelines for the development of the exam were given and the exam was delivered. Finally, with the evaluation carried out, it was extracted and digitized in Excel and then analyzed in SPSS.

\section{E. Data Analysis Method}

For the study, the descriptive analysis was carried out using various contingency tables, as well as bar graphs and for the inferential analysis, the non-parametric Mann-Whitney U test was applied to test hypotheses, analyzing these data in the EXCEL 2016 programs and SPSS 25. Statistical analyzes allow to measure the relationships between variables with a higher [31].

\section{F. Ethical Aspects}

The ethical aspects considered for carrying out this research were the authorization of the EAP Academic Professional School of Systems Engineering to apply the project-based learning method in the sixth cycle of the Private University in the morning and night shifts, as well as the application of the instruments were considered anonymous.

\section{RESULTS}

The results obtained from the research carried out are shown:

\section{A. Description of the Variable Network and Communication Competences I}

Table VI and Fig. 1 through the frequency bar diagram show that in the pretest and posttest of the control group they present similar results to $95 \%$ without change; while, in the pretest of the experimental group, $100 \%$ was found in the bad level and in the posttest of the experimental group: $21.1 \%$ was found in the bad level, $26.3 \%$ was found in the regular level and $52.6 \%$ was found good level, which shows a significant difference.

\section{B. Description of the Dimension Knowledge to Solve Local Area Network Design Problems}

Table VII and Fig. 2 through the frequency bar diagram show that in the pretest and posttest of the control group they present similar results, while in the experimental group, in the pretest $47.4 \%$ were found to be at a bad level, $52.6 \%$ was found at a regular level and in the post-test of the experimental group the improvements are observed, of which $10.5 \%$ were found at a bad level, $42.1 \%$ were found at a regular level and $47.4 \%$ were found at a good level, which shows a significant difference.

\section{Description of the Implementation Dimension of the Network Convergence}

Table VIII and Fig. 3 through the frequency bar diagram show that in the pretest and posttest corresponding to dimension 2, of which for the control group in the pretest it is observed that $80 \%$ of the students are in a bad level, $10 \%$ are at a regular level and $10 \%$ are at the good level, then in the posttest it increases slightly to $100 \%$ of the students are at the bad level, while in the experimental group, the $94.7 \%$ was found in a bad level, 5.3\% was found in a regular level and in the posttest of the experimental group the improvements are 
observed, of which $31.6 \%$ were found in a bad level, $15.8 \%$ were found in a regular level and $52.6 \%$ A good level was found, which has a clear significant difference.

TABLE VI. LEVELS IN THE NETWORK AND COMMUNICATIONS COMPETENCES I OF THE PRETEST AND POSTTEST

\begin{tabular}{|c|c|c|c|c|c|c|}
\hline & \multicolumn{5}{|c|}{ Networking and communications competences I } & \multirow{2}{*}{ Total } \\
\hline & & & Bad & Regular & Good & \\
\hline \multirow{4}{*}{ 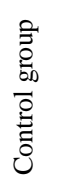 } & \multirow{2}{*}{ Pre } & fi & 19 & 1 & 0 & 20 \\
\hline & & $\%$ fi & $95.0 \%$ & $5.0 \%$ & $0.0 \%$ & 100.0 \\
\hline & \multirow{2}{*}{ Post } & fi & 19 & 1 & 0 & 20 \\
\hline & & $\% \mathrm{fi}$ & $95.0 \%$ & $5.0 \%$ & $0.0 \%$ & 100.0 \\
\hline \multirow{4}{*}{ 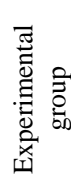 } & Pre & fi & 19 & 0 & 0 & 19 \\
\hline & & $\%$ fi & $100.0 \%$ & $0.0 \%$ & $0.0 \%$ & 100.0 \\
\hline & Post & fi & 4 & 5 & 10 & 19 \\
\hline & & $\% \mathrm{fi}$ & $21.1 \%$ & $26.3 \%$ & $52.6 \%$ & 100.0 \\
\hline
\end{tabular}

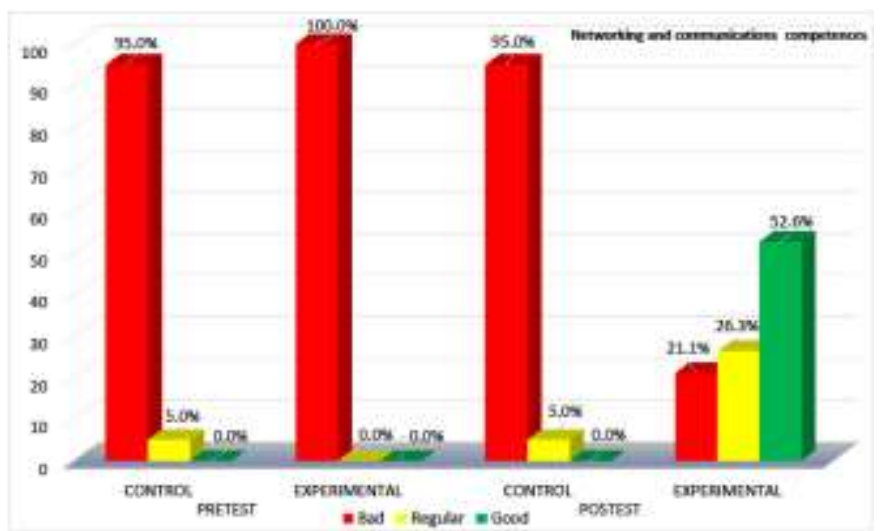

Fig. 1. Levels in Network and Communication Competences I of the Pretest and Posttest.

TABLE VII. LEVELS IN KNOWLEDGE TO SOLVE NETWORK DESIGN PROBLEMS OF LOCAL AREA OF PRETEST AND POSTTEST

\begin{tabular}{|c|c|c|c|c|c|c|}
\hline \multicolumn{6}{|c|}{ Knowledge to solve local area network design problems } & \multirow{2}{*}{ Total } \\
\hline & & & Bad & Regular & Good & \\
\hline \multirow{4}{*}{ 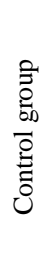 } & \multirow{2}{*}{ Pre } & fi & 13 & 6 & 1 & 20 \\
\hline & & $\%$ fi & $65.0 \%$ & $30.0 \%$ & $5.0 \%$ & 100.0 \\
\hline & \multirow{2}{*}{ Post } & fi & 14 & 6 & 0 & 20 \\
\hline & & $\%$ fi & $70.0 \%$ & $30.0 \%$ & $0.0 \%$ & 100.0 \\
\hline \multirow{4}{*}{ 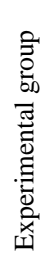 } & Pre & fi & 9 & 10 & 0 & 19 \\
\hline & & $\%$ fi & $47.4 \%$ & $52.6 \%$ & $0.0 \%$ & 100.0 \\
\hline & Post & fi & 2 & 8 & 9 & 19 \\
\hline & & $\%$ fi & $10.5 \%$ & $42.1 \%$ & $47.4 \%$ & 100.0 \\
\hline
\end{tabular}

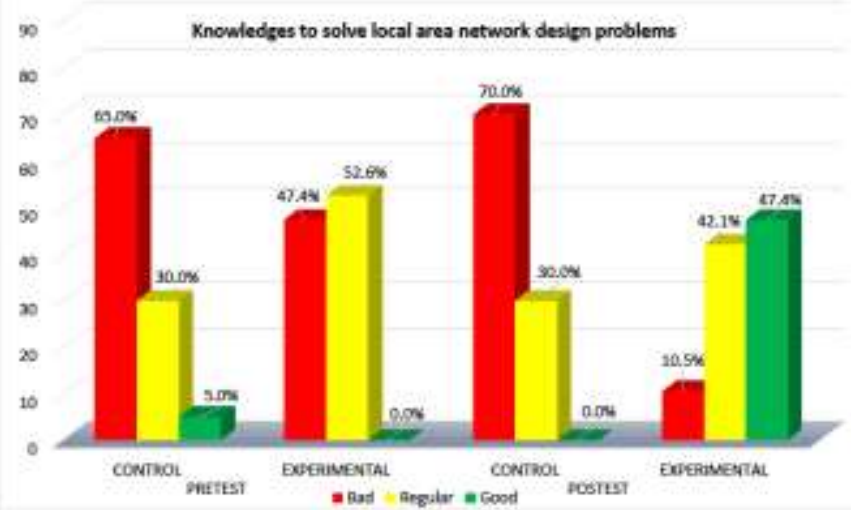

Fig. 2. Levels of Knowledge to Solve Pretest and Posttest Local Area Network Design Problems.

TABLE VIII. LEVELS IN THE IMPLEMENTATION OF THE CONVERGENCE OF THE PRETEST AND POSTTEST NETWORK

\begin{tabular}{|c|c|c|c|c|c|c|}
\hline \multicolumn{6}{|c|}{ Implementation of network convergence } & \multirow{2}{*}{ Total } \\
\hline & & & Bad & Regular & Good & \\
\hline \multirow{4}{*}{ 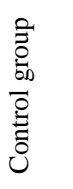 } & \multirow{2}{*}{ Pre } & fi & 16 & 2 & 2 & 20 \\
\hline & & $\%$ fi & $80.0 \%$ & $10.0 \%$ & $10.0 \%$ & 100.0 \\
\hline & \multirow{2}{*}{ Post } & fi & 20 & 0 & 0 & 20 \\
\hline & & $\%$ fi & $100.0 \%$ & $0.0 \%$ & $0.0 \%$ & 100.0 \\
\hline \multirow{4}{*}{ 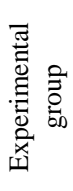 } & Pre & fi & 18 & 1 & 0 & 19 \\
\hline & & $\%$ fi & $94.7 \%$ & $5.3 \%$ & $0.0 \%$ & 100.0 \\
\hline & Post & fi & 6 & 3 & 10 & 19 \\
\hline & & $\%$ fi & $31.6 \%$ & $15.8 \%$ & $52.6 \%$ & 100.0 \\
\hline
\end{tabular}

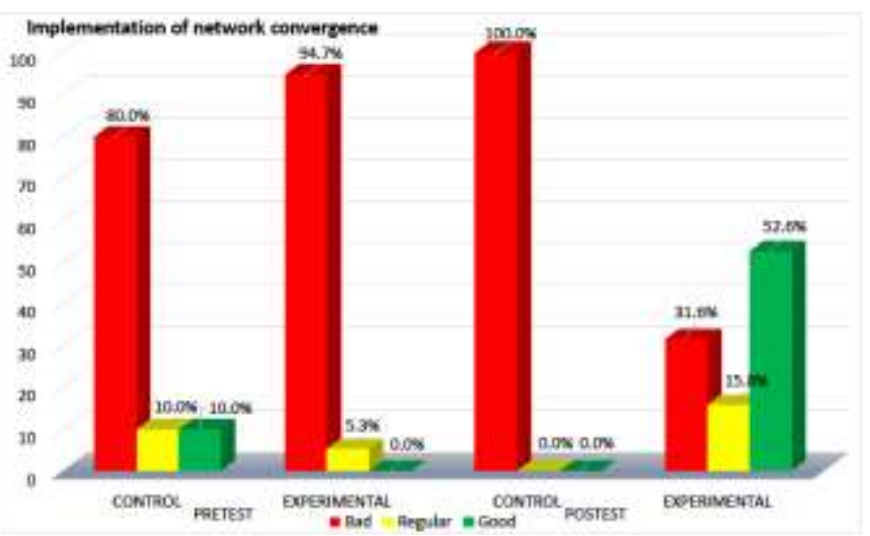

Fig. 3. Levels in the Implementation of the Convergence of the Pretest and Posttest Network.

\section{Description of the Implementation Dimension of Network Administration}

Table IX and Fig. 4 through the frequency bar diagram shows the pretest and posttest of dimension 3 , in the control group in the pretest it is observed that $50 \%$ of the students are at a bad level, $45 \%$ at the regular level and $5 \%$ at the good level, then in the posttest it decreases slightly to $45 \%$ of students are at the bad level, 50\% at the regular level and 5\% at the good level, while the experimental group, in the pretest, found the $63.2 \%$ in bad level, $36.8 \%$ in regular level and in the 
posttest of the experimental group $10.5 \%$ of students in bad level, $36.8 \%$ in regular level and $47.4 \%$ in good level, have significant difference.

TABLE IX. LEVELS IN THE ADMINISTRATION OF PRETEST AND POSTTEST NETWORKS

\begin{tabular}{|c|c|c|c|c|c|c|}
\hline \multicolumn{6}{|c|}{ Network administration } & \multirow{2}{*}{ Total } \\
\hline & & & Bad & Regular & Good & \\
\hline \multirow{4}{*}{ 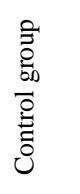 } & \multirow{2}{*}{ Pre } & fi & 10 & 9 & 1 & 20 \\
\hline & & $\%$ fi & $50.0 \%$ & $45.0 \%$ & $5.0 \%$ & 100.0 \\
\hline & \multirow{2}{*}{ Post } & fi & 9 & 10 & 1 & 20 \\
\hline & & $\% \mathrm{fi}$ & $45.0 \%$ & $50.0 \%$ & $5.0 \%$ & 100.0 \\
\hline \multirow{4}{*}{ 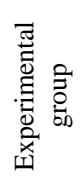 } & Pre & fi & 12 & 7 & 0 & 19 \\
\hline & & $\% \mathrm{fi}$ & $63.2 \%$ & $36.8 \%$ & $0.0 \%$ & 100.0 \\
\hline & Post & fi & 3 & 7 & 9 & 19 \\
\hline & & $\%$ fi & $15.8 \%$ & $36.8 \%$ & $47.4 \%$ & 100.0 \\
\hline
\end{tabular}

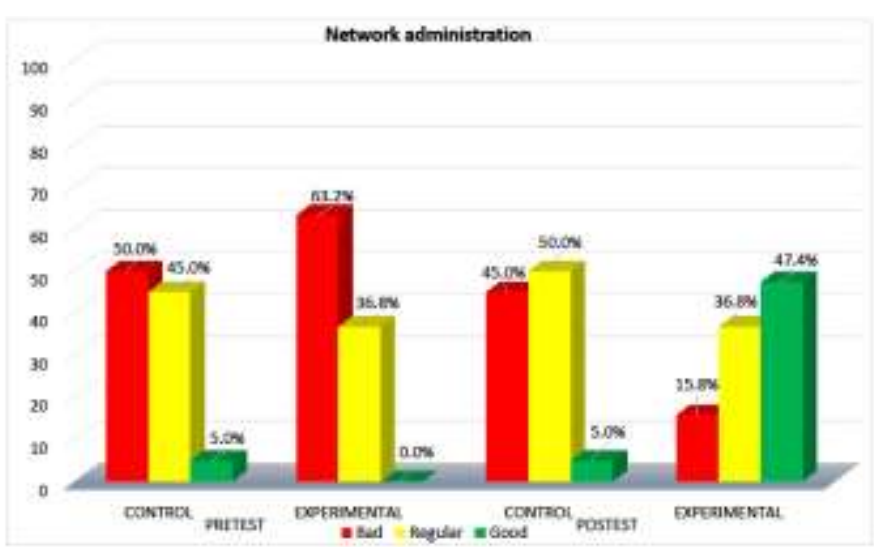

Fig. 4. Levels in Pretest and Posttest Network Administration.

\section{E. Normality Test}

The Kolmogorov-Smirnov method was used to check if the results follow a normal distribution. To do this, the Kolmogorov-Smirnov method is used to choose the corresponding test, due to the sample size being equal to or greater than 30 .

Accordingly, in Table $\mathrm{X}$, the corresponding significance values are shown to be less than $\alpha=0.05$; therefore, Ho is rejected, that is, the data do not follow a normal distribution. However, the 3 rd is found. Posttest dimension with data record greater than $\alpha=0.05$, but corresponds to the $6^{\text {th }}$ part of the total of the three dimensions analyzed, as larger records with greater significance. Consequently, non-parametric tests will be applied for all inferential studies. Therefore, the MannWhitney $\mathrm{U}$ test will be used.

\section{F. General Hypothesis Testing}

Ho: Project-based learning does not positively and significantly impact on network and communications competences I, in Engineering students, Lima 2020.

Ha: Project-based learning has a positive and significant impact on network and communication competences I, in Engineering students, Lima 2020.
TABLE X. RESULTS OF THE KINDNESS OF ADJUSTMENT TEST FOR THE VARIABLE NETWORK AND COMMUNICATIONS COMPETENCES I

\begin{tabular}{|l|l|l|l|}
\hline \multirow{2}{*}{} & \multicolumn{3}{|l|}{ Kolmogorov-Smirnov } \\
\cline { 2 - 4 } & Statistical & gl. & Sig. \\
\hline Pretest_D1_Knowledge &, 182 & 39 & 002 \\
\hline Pretest_D2_Implementation &, 254 & 39 &, 000 \\
\hline Pretest_D3_Administracion &, 168 & 39 & 007 \\
\hline Posttest_D1_Knowledge &, 152 & 39 & 024 \\
\hline Posttest_D2_Implementation &, 282 & 39 &, 000 \\
\hline Posttest_D3_Administracion &, 140 & 39 & 051 \\
\hline
\end{tabular}

TABLE XI. U MANN-Whitney Test to Test the General Hypothesis

\begin{tabular}{|l|l|l|l|}
\hline \multirow{2}{*}{ Statistical } & \multicolumn{2}{|l|}{ Group } & U test \\
\cline { 2 - 4 } & Control $(\mathrm{n}=20)$ & Experimental $(\mathrm{n}=19)$ & Mann-Whitney \\
\hline Pretest & \multicolumn{2}{|l|}{} \\
\hline $\mathrm{U}=172,500$ & 19.08 & $\mathrm{Z}=-, 498$ \\
\hline Average range & 20.88 & 362.50 & $p=, 618$ \\
\hline Sum of ranges & 417.50 & 28.37 & $\mathrm{Z}=-4,488$ \\
\hline Posttest & 539.00 & $p=.000$ \\
\hline $\mathrm{U}=31,000$ & 12.05 &
\end{tabular}

According to the result described in Table XI, the network and communications competencies variable I, the control and experimental groups in the posttest show the U-Mann-Whitney $=31,000$ and $Z=-4,488$, evidence of $p$ less than $\alpha=0,05$; therefore $\mathrm{Ho}$ is rejected and $\mathrm{Ha}$ is accepted, thus concluding that the variable network and communications competences I of the experimental group shows a significant improvement with respect to the control group, affirming that project-based learning positively and significantly impacts on networking and communications competences I.

\section{G. Specific Hypothesis Test 1}

Ho: Project-based learning does not positively and significantly impact knowledge to solve local area network design problems in Engineering students, Lima 2020.

Ha: Project-based learning positively and significantly impacts knowledge to solve local area network design problems in Engineering students, Lima 2020.

TABLE XII. MANN-WhitNey Test U To Test SPECIFIC Hypothesis 1

\begin{tabular}{|l|l|l|l|}
\hline \multirow{2}{*}{ Statistical } & \multicolumn{2}{|l|}{ Group } & U test \\
\cline { 2 - 4 } & Control $(\mathrm{n}=20)$ & Experimental $(\mathrm{n}=19)$ & Mann-Whitney \\
\hline Pretest & \multicolumn{2}{|l|}{} \\
\hline $\mathrm{U}=183,500$ & 20.34 & $\mathrm{Z}=-, 187$ \\
\hline Average range & 19.68 & 386.50 & $p=, 852$ \\
\hline Sum of ranges & 393.50 & 28.79 & $\mathrm{Z}=-4,748$ \\
\hline Posttest & 547.00 & $p=.000$ \\
\hline $\mathrm{U}=23,000$ &
\end{tabular}


According to the result described in Table XII, the knowledge dimension to solve local area network design problems, the control and experimental groups in the posttest show the U-Mann-Whitney $=23,000$ and $\mathrm{Z}=-4,748$, it is evident $\mathrm{p}$ lower at $\alpha=0.05$; therefore Ho is rejected and $\mathrm{Ha}$ is accepted.

\section{H. Specific Hypothesis Test 2}

Ho: Project-based learning does not positively and significantly impact the implementation of network convergence in Engineering students, Lima 2020.

Ha: Project-based learning has a positive and significant impact on the implementation of network convergence in engineering students, Lima 2020.

According to the result described in Table XIII, the implementation dimension of network convergence, the control and experimental groups in the posttest show the U-MannWhitney $=56,000$ and $Z=-3,975$, with evidence of $p$ less than $\alpha=0,05$; therefore Ho is rejected and Ha is accepted.

\section{Specific Hypothesis Test 3}

Ho: Project-based learning does not have a positive and significant impact on the administration of networks in Engineering students, Lima 2020.

Ha: Project-based learning positively and significantly impacts network administration in engineering students, Lima 2020.

TABLE XIII. MANN-Whitney TeSt U to TEST SPECIFIC Hypothesis 2

\begin{tabular}{|l|l|l|l|}
\hline \multirow{2}{*}{ Statistical } & \multicolumn{2}{|l|}{ Group } & U test \\
\cline { 2 - 4 } & Control $(\mathrm{n}=20)$ & Experimental $(\mathrm{n}=19)$ & Mann-Whitney \\
\hline Pretest & \multicolumn{2}{|l|}{} \\
\hline $\mathrm{U}=185,000$ & 20.26 & $\mathrm{Z}=-, 154$ \\
\hline Average range & 19.75 & 385.00 & $p=, 878$ \\
\hline Sum of ranges & 395.00 & 27.05 & $\mathrm{Z}=-3,975$ \\
\hline Posttest & 514.00 & $p=.000$ \\
\hline $\mathrm{U}=56,000$ & 13.30 &
\end{tabular}

TABLE XIV. Mann-Whitney Test U to TeSt SPECIFIC Hypothesis 3

\begin{tabular}{|l|l|l|l|}
\hline \multirow{2}{*}{ Statistical } & \multicolumn{2}{|l|}{ Group } & U test \\
\cline { 2 - 4 } & Control $(\mathrm{n}=20)$ & Experimental $(\mathrm{n}=19)$ & Mann-Whitney \\
\hline Pretest & \multicolumn{2}{|l|}{} \\
\hline $\mathrm{U}=169,500$ & 18.92 & $\mathrm{Z}=-, 588$ \\
\hline Average range & 21.03 & 359.50 & $p=, 557$ \\
\hline Sum of ranges & 420.50 & 26.55 & $\mathrm{Z}=-3,533$ \\
\hline Posttest & 504.50 & $p=.000$ \\
\hline U $=65,500$ & 13.78 & \\
\hline Average range & \multicolumn{2}{|l}{} \\
\hline Sum of ranges & 275.50 &
\end{tabular}

According to the result described in Table XIV, the network administration dimension, the control and experimental groups in the posttest show the U-Mann-Whitney $=65,000$ and $Z=-3,533$, with $p$-value less than $\alpha=0.05$; therefore Ho is rejected and $\mathrm{Ha}$ is accepted.

\section{DISCUSSION}

Regarding the validation of the general hypothesis, the statistical results obtained values of $\mathrm{Z}=-4.488$ and $\mathrm{p}$ value of 0.000 (see Table XI), so that project-based learning positively and significantly impacts on network and communication competences I, in engineering students, Lima 2020, for which the results obtained in the post-test, it was determined that the number of students who are at the regular and good level both are approximately $80 \%$ of the total population of the experimental group (see Table VI), verifying that the use of the programmed designed project-based learning to improve the learning competences of the communication networks I course, improved the understanding of it in all its dimensions.thus confirming the importance of using the project-based learning methodology [27].

Regarding the validation of the specific hypotheses, the analysis by dimensions was carried out, in which dimension 1 consists of 8 questions, dimension 2 consists of 3 questions and dimension 3 consists of 9 questions, totaling 20 questions. For the confirmation of the specific hypothesis 1 ; obtained values of $\mathrm{Z}=-4,748$ and $\mathrm{p}$ value of 0.000 in the posttest of the experimental group compared to a $\mathrm{Z}=-$, 187 and $\mathrm{p}$ value of 0.852 of the control group, thus also at the percentage level it is observed that in the pretest in the bad level they were $47.4 \%$ of students and in the post-test the percentage dropped to $10.5 \%$ of students, thus it is also observed that in the case of the regular level in the pretest, $52.6 \%$ of students are observed and in the posttest the percentage dropped to 42 .

To validate the specific hypothesis 2 ; values of $\mathrm{Z}=-, 154$ were obtained greater than -1.96 (critical point) and a $\mathrm{p}$ value $=$ 0.878 in the pretest there are initially no differences and then when obtaining a $\mathrm{Z}=-3.975$ and a $\mathrm{p}$ value $=0.000$ in the posttest, finding significant differences between the control group and the experimental group, as well as at the percentage level, it is observed that in the pretest the bad level was $94.7 \%$ of students and in the posttest the percentage fell to $31.6 \%$ of students, it is also observed that in the case of the regular level in the pretest, $5.3 \%$ of students are observed and in the posttest the percentage increased to $15.8 \%$ of students and finally in the experimental group, a significant growth percentage at the good level, being initially $0.0 \%$ to $52.6 \%$ in the posttest in the pretest.

To confirm the specific hypothesis 3 ; values of $Z=-3,533$ and $p$ value of 0.000 were obtained in the posttest of the experimental group compared to a $\mathrm{Z}=-, 588$ and $\mathrm{p}$ value of 0.557 of the control group, as well as percentage results were obtained in order to observe the changes between the pretest and posttest of the control group as well as the experimental group, in which it is observed that in the pretest in the bad level were $63.2 \%$ of students and in the posttest the percentage fell to $15.8 \%$ of students, Thus, it is also observed that in the case of the regular level in the pretest, $36.8 \%$ of students were observed and in the posttest, the percentage was maintained at 
$36.8 \%$ of students, and finally, in the experimental group, a percentage of significant growth in the good level, being initially 0 in the pretest, $0 \%$ to $47.4 \%$ in the posttest. Thus, according to the statistical results found in specific hypothesis 3 , project-based learning positively and significantly impacts network administration in engineering students, Lima (see Fig. 4).

\section{CONCLUSIONS}

We showed that project-based learning caused a positive and significant impact on the dependent variable network and communication competences I, in engineering students, Lima 2020, because the significance level was obtained Sig. $=0.000$ less than $\alpha=0,05(\mathrm{p}<\alpha)$ and $Z=-4,488$, indicating that the proposed model is appropriate.

It was verified that project-based learning caused a positive and significant impact on the knowledge dimension to solve local area network design problems in engineering students, Lima 2020, due to the fact that it reached the significance level Sig. $=0.000$ less than $\alpha=0.05(p<\alpha)$ and $Z=-4,748$, demonstrating that the proposed model is acceptable.

Project-based learning was found to have a positive and significant impact on the implementation dimension of network convergence in engineering students, Lima 2020, because the level of significance Sig. $=0.000$ is less than $\alpha=0,05(\mathrm{p}<\alpha)$ and $\mathrm{Z}=-3,975$, indicating that the proposed model is appropriate.

Project-based learning was shown to have a positive and significant impact on the dimension of network administration in Engineering students, Lima 2020, because the level of significance Sig. $=0.000$ is less than $\alpha=0.05(\mathrm{p}<\alpha)$ and $\mathrm{Z}=-$ 3,533 of the experimental group in the posttest calculation, confirming that the proposed model is valid.

\section{RECOMMENDATIONS}

It is recommended to both public and private universities to implement the use of the project-based learning program to improve competences in the course of networks and communications, in order to use it as a model for their best student performance in classes, as well as motivate them in the investigations of all professional academic activities permanently in order to contribute to individual and teamstudent-teacher-university improvement so that they can interpret, design, plan and implement various solutions to the same problem, both personally, family, social and professionally.

We alos suggest to train the teachers of the networks and communications course to learn the project-based learning methodology, to use it as a reference model for class sessions, since activities structured by a sequence of phases are developed to carry out prototype professional projects, managing to generate better research among teachers, thus improving the levels of competences for the knowledge dimension to solve local area network design problems.

It is recommended to develop the implementation dimension of network convergence, through the project-based learning program, in order to improve your competences to successfully face the new challenges of emerging technological trends. Finally, it is recommended to learn the network administration dimension through project-based learning, in order to improve technological organizations, closing the gap in the job sector.

\section{REFERENCES}

[1] C. N.Casimiro Urcos, W. H. Casimiro Urcos y J. F. Casimiro Urcos, "Desarrollo de competencias profesionales en estudiantes universitarios". Conrado, vol.15, n. ${ }^{\circ}$ 70, pp.312-319. Epub 02-Dic-2019. ISSN 2519-7320. http://scielo.sld.cu/scielo.php?script=sci_arttext\& pid=S1990-86442019000500312\&lng=es\&nrm=iso.

[2] ITU. Conjunto de Herramientas para las Habilidades Digitales. SuizaGinebra, 2018. https://www.itu.int/en/ITU-D/Digital-Inclusion/ Documents/ Digital- Competences-Toolkit_Spanish.pdf.

[3] Unesco. Qué hace la UNESCO en materia de educación superior, May 2018.https://es.unesco.org/themes/educacion-superior/accion.

[4] S. Núñez López, J.E. Ávila Palet y S. L. Olivares Olivares, "The development of critical thinking through problem-based learning", RIES, México, UNAM-IISUE/Universia, vol. 8, n. ${ }^{\circ}$ 23, pp. 84-103, Agosto 2016. https://www.redalyc.org/jatsRepo/2991/299152904005 /html/index.html

[5] MTPE. Subsector Telecomunicaciones: Ocupaciones frecuentes y oferta formativa a nivel nacional, 2019. http://cdn.www.gob.pe/uploads/ document/file/458911/telecomunicaciones.pdf.

[6] C. Sotomayor-Beltran and L. Andrade-Arenas, "A spatial assessment on internet access in Peru between 2007 and 2016 and its implications in education and innovation," 2019 IEEE 1st Sustainable Cities Latin America Conference (SCLA), Arequipa, Peru, 2019, pp. 1-4.

[7] SUNEDU, "Informe bienal sobre la realidad universitaria peruana" Sunedu, Lima-Perú, 2018. https://www.sunedu.gob.pe/informe-bienalsobre-realidad-universitaria/.

[8] V. F. Martins, P. N.M. Sampaio, A. J. A. Cordeiro and B. Ferreira Viana, "Implementing a Data Network Infrastructure Course using a Problem-based Learning Methodology". Journal of Information Systems Engineering \& Management, vol. 3, n. ${ }^{\circ}$ 2, pp. 1-7, April 2018. DOI: https://doi.org/10.20897/jisem.201810.

[9] M. Beier, M. Kim, A. Saterbak, V. Leautaud, S. Bishnoi and J.M. Gilberto, "The effect of authentic project - based learning on attitudes and career aspirations in STEM". Journal of Research in Science Teaching, Mayo 2018. DOI: https://doi.org/10.1002/tea.21465.

[10] M. Fernández Redondo, C. Hernández Espinosa, and J. Sales Gil, "Learning of Computer Networks through the use of Projects in a Video Game Degree", Zaragoza-España, pp. 593-598, 2017. DOI: 10.26754 / CINAIC.2017.000001_124.

[11] L. Qin, "Design and Realization of Project-based Computer English Learning System". International Journal of Emerging Technologies in Learning, vol. 12, n. ${ }^{\circ}$ 08, pp. 128-136, June 2017. DOI: https://doi.org/10.3991/ijet.v12.i08.7147.

[12] C. Baluarte Araya, "Project based Learning Application Experience in Engineering Courses: Database Case in the Professional Career of Systems Engineering". International journal of computer science and advanced applications (IJACSA), vol. 11, n. ${ }^{\circ} 3$, pp. 128-136, 2020. http://dx.doi.org/10.14569/IJACSA.2020.0110316.

[13] L. Torres, "Plataforma virtual para mejorar el rendimiento en una asignatura del plan curricular de la escuela de tecnologías de la información, Senati", tesis doctoral, escuela de posgrado de la Universidad Peruana Cayetano Heredia, Lima, Perú, 2019. http://repositorio.upch.edu.pe/bitstream/handle/upch/7726/Plataforma_T orresArgomedo_Leonardo.pdf?sequence $=1$ \&isAllowed=y.

[14] F. Rodríguez, "Aprendizaje basado en proyectos en el nivel de competencias investigativas en estudiantes de Instituto Pedagógico, Trujillo, 2017", tesis doctoral, escuela de posgrado de la Universidad Cesar Vallejo, Lima, Perú, 2018. http://repositorio.ucv.edu.pe/ bitstream/handle/20.500.12692/22688/rodriguez_vf.pdf?sequence=1\&is Allowed=y.

[15] D. G. Hostia Luque, "Aprendizaje basado en proyectos colaborativos y competencias de los estudiantes de tercer año de Ingeniería de Sistemas de la Universidad Nacional San Luis Gonzaga de Ica”, tesis de maestría, 
escuela de posgrado de la Universidad Nacional San Luis Gonzaga de Ica, Lima, Perú, 2018. http://repositorio.une.edu.pe/bitstream/handle/ UNE/2467/TM\%20CE-Du\%204071\%20H1\%20-

$\% 20$ Hostia $\% 20$ Luque.pdf?sequence $=1 \&$ is Allowed=y.

[16] L. M. Zegarra Ramírez, "Efectos de la aplicación de la metodología de aprendizaje basado en proyectos en el desarrollo de competencias en el curso de procesos de manufactura II". tesis de maestría, escuela de posgrado de la Universidad Peruana Cayetano Heredia, Lima, Perú, 2019. http://repositorio.upch.edu.pe/bitstream/handle/upch/1443/Efectos _ZegarraRamirez_Leonor.pdf?sequence $=1$ \&isAllowed $=\mathrm{y}$.

[17] A. Rofieq, R. Latifa, E. Susetyarini and P. Purwatiningsih, "Projectbased learning: Improving students' activity and comprehension through lesson study in senior high school". JPBI (Jurnal Pendidikan Biologi Indonesia), vol. 5, n. ${ }^{\circ}$ 1, pp. 41-50, March 2019. DOI: https://doi.org/10.22219/jpbi.v5i1.7456.

[18] J. Gutiérrez, G. De la Puente, A. Martínez, and E. Piña. Aprendizaje basado en problemas. Editorial Universidad Nacional Autónoma de México, 2013. https://portalacademico.cch.unam.mx/materiales/libros/ pdfs/librocch_abp.pdf.

[19] K. Sormunen, K. Juuti and J. Lavonen, "Maker-Centered Project-Based Learning in Inclusive Classes: Supporting Students' Active Participation with Teacher-Directed Reflective Discussions". Int J of Sci and Math Educ 18, pp. 691-712, April 2020. DOI: https://doi.org/10.1007/s10763019-09998-9.

[20] I. Saputra, S. Joyoatmojo, and H. Harini,"The implementation of project-based learning model and audio media Visual can increase students' activities". International Journal of Multicultural and Multireligious Understanding, vol. 5, n. ${ }^{\circ}$ 4, pp. 166-174, 2018. DOI: http://dx.doi.org/10.18415/ijmmu.v5i4.224.

[21] M. De la Puente, D. Guerra, C. de Oro and C. McGarry, "Undergraduate students' perceptions of Project-Based Learning (PBL) effectiveness: A case report in the Colombian Caribbean. Cogent Education", Cogent Education, vol. 6, n. ${ }^{\circ}$ 1, 1616364, pp. 1- 17, May 2019. DOI: https://doi.org/10.1080/2331186X.2019.1616364.

[22] G. Geitz and J. de Geus, "Design-based education, sustainable teaching, and learning", Cogent Education, vol. 6, n. ${ }^{\circ}$ 1, 1647919, pp. 1- 15, July 2019 . DOI: https://doi.org/10.1080/2331186X.2019.1647919.
[23] F. D. Mendoza Vargas. "Relación Entre La Actitud Experiencial y La Utilización De Simuladores Como Herramienta Pedagógica". tesis de maestría, facultad de ciencias administrativas y contables de la Universidad de La Salle, Bogotá, Colombia, Noviembre 2015. https://ciencia.lasalle.edu.co/cgi/viewcontent.cgi?article=1481\&context= maest_administracion.

[24] UCH. Silabo de Redes y Comunicaciones I. Escuela Profesional de Ingeniería de Sistemas 2019, diciembre 2019, Lima, Perú.

[25] C. M. Amador Ortiz y L. Velarde Peña, "ICT Competences in students of higuer education, a case study". RIDE, vol. 10, n. ${ }^{\circ} 19$, ago. 2019. DOI: https://doi.org/10.23913/ride.v10i19.515.

[26] C. De Anda, N. Galaviz y R. Santiago. Tecnología de la Información 1. Editorial Gyros S.A. Ciudad Universitaria Culiacán, Sinaloa, México, Agosto 2019. https://issuu.com/profejraul/docs/libro_tiyc_1_uas.

[27] J. F. Kurose and K. W. Ross. Redes de computadoras. un enfoque descendente. Editorial Pearson Educación, S. A. Madrid, España. 7ma, 2017. Edición. https://www.academia.edu/40738627/Redes_de_computadoras_Un_enfo que_descendente_7a_Edici\%C3\%B3n.

[28] A. López y P. Díaz. "Capítulo 3: Investigación, emprendimiento y TIC, elementos de una propuesta pedagógica en la Universidad Popular del Cesar", en Congreso Internacional sobre el Enfoque Basado en Competencias, por editorial Corporacion CIMTED, Colombia, vol. 10, n. ${ }^{\circ}$ 1, pp. 146-162, Marzo 2018. http://memoriascimted.com/wpcontent/uploads/2016/02/Memorias-CIEBC2018.pdf.

[29] C. de Pelekais, O.El kadi, C. Seijo y N. Neuman. El ABC de la Investigación. Pauta Pedagógica. Septima Edicion, Maracaibo, Venezuela. Editorial: Astro Data S.A., 2015.

[30] H. Naupas, E. Mejía, E. Novoa y A. Villagómez. Metodología de la investigación: cuantitativa - cualitativa y redacción de la tesis, 4ta. Edicion. Bogotá, Colombia: Ediciones de la U., Abril 2014.

[31] W. Rengel y M. Giler. Publicar investigación científica Metodología y desarrollo, 1ra. Edicion, Manabi-Ecuador, Editorial: Mar Abierto, 2018. 